ABDI: Jurnal Pengabdian dan Pemberdayaan Masyarakat ISSN: 2656-369X (Print), 2684-8570 (Online)

Volume 1 No. 2, Desember 2019

http://abdi.ppj.unp.ac.id/index.php/abdi

Email: abdi@ppj.unp.ac.id

DOI: https://doi.org/10.24036/abdi.vli2.13

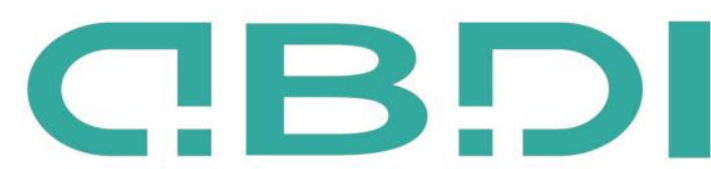

ABDI: JURNAL PENGABDIAN DAN PEMBERDAYAAN MASYARAKAT

\title{
Penggunaan Mesin Modifikasi Jamu Tradisional Untuk Meningkatkan Hasil Produksi
}

\author{
Rosita Dwi Ferdiani $^{1}$, Udik Yudiono ${ }^{2}$, Tatik Retno Murniasih ${ }^{3}$ \\ ${ }^{1,2,3}$ Universitas Kanjuruhan Malang
}

Email: rositadf@unikama.ac.id., u_yudiono@unikama.ac.id., tretnom@unikama.ac.id.

\begin{abstract}
Abstrak
Proses produksi jamu tradisional dengan mesin manual memerlukan waktu yang relatif lama. Proses produksi yang lama akan menghasilkan produksi jamu yang sedikit dan juga resiko tumbuhnya bakteri. Tujuan dari pengabdian ini yaitu membuat mesin modifikasi jamu untuk meningkatkan produksi jamu. Pengabdi melalui kegiatan PKM (Program Kemitraan Masyarakat) menawarkan metode pada mitra antara lain diskusi, pelatihan dan pendampingan. Diskusi berguna untuk menggali kelemahan dan kelebihan mitra. Pelatihan dibantu ahli mesin terkait pengoperasian mesin modifikasi jamu dan perawatannya. Sedangkan pendampingan dilakukan pengabdi mulai dari penyediaan mesin modifikasi jamu sampai produksi jamu. Hasil pengabdian menunjukkan kegiatan berjalan dengan lancar dengan penjadwalan yang sudah disepakati pengabdi dan mitra. Selain itu mitra juga berpartisipasi aktif dalam kegiatan pengabdian PKM ini. Penggunaan mesin modifikasi jamu dapat meningkatkan produksi jamu mitra.
\end{abstract}

Kata kunci: Jamu tradisinal, Meningkatkan produksi, Mesin modifikasi

\section{Abstract}

The process of producing traditional herbal medicine with manual machines requires a relatively long time. The long production process will produce less herbal production and also the risk of bacterial growth. The aim of this service is to make a medicinal modification machine to increase herbal production. Servants through PKM (Community Partnership Program) activities offer partners methods including discussion, training and mentoring. Discussion is useful for exploring partners' weaknesses and strengths. The training was assisted by machinists related to the operation of the herbal modification machine and its maintenance. While the assistance is carried out starting from the provision of herbal modification machines to herbal production. The results of the service show that the activity went smoothly with the scheduling agreed upon by the servants and partners. In adition partners also actively participated in this PKM service activities. The use of herbal modification machines can increase partner herbal medicine production.

Keyword: Increase production, Machine modification, Traditional herbal medicine

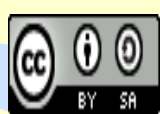




\section{Pendahuluan}

Jamu tradisional merupakan minuman khas Indonesia yang bermanfaat untuk menjaga kesehatan dan pencegahan penyakit. Harga jamu tradisional yang murah menjadi keuntungan tersendiri bagi konsumen penikmat jamu (Mohammad, 2007). Namun sayang, keberadaan jamu sudah sedikit terlupakan karena semakin banyaknya obat kimia yang beredar di pasaran. Padahal obat-obat kimia tentunya memberikan efek negatif apabila dikomsumsi dalam jangka panjang (Mangan, 2003). Tetapi pada tahun-tahun terakhir, penggunaan obat tradisional khususnya jamu, terus meningkat sehingga membuat WHO melalui World Health Asembly merekomendasikan penggunaan obat tradisional dalam pemeliharaan kesehatan masyarakat, pencegahan dan pengobatan penyakit, terutama untuk penyakitpenyakit kronis, seperti kanker.

Tanaman jamu tradisional dapat tumbuh subur di daerah iklim tropis terutama di daerah pegunungan seperti di desa Ngembal, Kecamatan Tutur, kabupaten Pasuruan, Jawa Timur. Sebagaian besar masyarat memanfaatkan lahan kosong untuk menanam berbagai tanaman obat seperti kunyit, kencur, daun sirih, jahe. Nilai jual yang rendah pada tanaman obat membuat tanaman obat kurang menjadi perhatian masyarakat setempat. Menurut survey di pasar daerah Purwosari, Pasuruan, rata harga kunyit per kg adalah Rp 18.000,-. Sedangkan untuk harga kunyit kering rajangan dipatok dengan harga Rp. 45.000,- sampai dengan Rp. 50.000,-. Berdasarkan wawancara dengan petani, harga kunyit basah dijual dengan harga Rp 3.000 sampai Rp. 4.000,-. Dapat disimpulkan bahwa harga kunyit mengalami penurunan harga yang sangat signifikan. Untuk harga jahe gajah, dipatok dengan harga antara Rp. 18.000,- sampai Rp. 20.000,-- Harga dari petani jahe berkisar antara RP. 2.500 - Rp. 3.000,untuk jahe basah. Apabila sudah dikeringkan bisa mencapai harga Rp. 6000,-. Berdasarkan harga jahe dan kunyit ditingkat petani dan dipasar terdapat perbedaan harga yang sangat signifikan. Untuk mendongkrak perekonomian petani tanaman obat di Desa Ngembal, maka didirikan sebuah usaha yang berbahan baku tanaman obat.

Salah satu usaha rumah tangga yang memanfaatkan tanaman obat adalah usaha pembuatan minuman jamu tradisional yang dipimpin oleh ibu Erni (39 tahun). Ibu Erni memanfaatkan tanaman obat yang selama ini tersedia tetapi kurang dimanfaatkan oleh masyarakat sekitar menjadi produk minuman jamu tradisional. Tentunya dengan adanya usaha ini telah mengangkat perekonomian petani tanaman obat yang berada di desa Ngembal, Kec. Tutur, Kab. Pasuruan. Ibu Erni merintis usahanya mulai tahun 2014, yang beralamat di Jalan Krajan Barat, Desa Ngembal, memproduksi jamu dengan produk andalannya adalah beras kencur dan sinom dengan kapasitas produksi per hari kurang lebih 50 - 60 botol ukuran $400 \mathrm{ml}$ dan 25-35 botol ukuran 1 liter, dan akan meningkat apabila menjelang akhir pekan atau menjelang lebaran. Harga perbotol ukuran $400 \mathrm{ml}$ adalah Rp 5000,- dan botol ukuran 1 liter adalah Rp 8000,-. Usaha ini bermodal awal kurang lebih Rp. 1.500.000,-, dengan keuntungan Rp. 3.700.000,- juta perbulan. Produk jamu milik Ibu Erni dipasarkan di sekitar desa Ngembal dan di kawasan wisata Bakti Alam yang terletak di Kecamatan Tutur. Daerah pemasaran ini belum bisa menjangkau seluruh daerah di Pasuruan, dikarenakan kurangnya media untuk memasarkan produk serta daya tahan minuman jamu tradisional ini hanya dapat bertahan selama 3 hari pada suhu normal, dan bertahan 1 minggu apabila disimpan di dalam lemari pendingin. Pada saat ini sudah mempunyai 4 karyawan dengan 2 orang yang bertugas meracik jamu, 1 orang karyawan sebagai kurir yang mengantar jamu ke konsumen dan 1 orang yang menjaga stand jamu di daerah kawasan wisata bhakti alam. Sekali produksi perharinya, usaha ibu Erni menghabiskan $5 \mathrm{~kg}$ jahe, $3 \mathrm{~kg}$ kunir, $8 \mathrm{~kg}$ kencur, $4 \mathrm{~kg}$ beras dan 5 kg gula. Proses produksi pembuatan beras kencur ini dimulai dari pemilihan bahan, pembersihan bahan kencur, jahe, dan kunir, pemblenderan bahan supaya lebih halus, perebusan, dan penyaringan sehingga membutuhkan waktu yang lama dalam sekali produksi dan membutuhkan banyak tenaga kerja. Hal ini tentunya, tidak sebanding dengan produk yang dihasilkan. Misalkan untuk perebusan masih digunakan panci 10 liter dan disaring sedikit demi sedikit sehingga membutuhkan waktu yang relatif lama sekitar 7 jam dalam sekali produksi. Proses produksi jamu yang selama ini dilakukan dapat dilihat pada Gambar 1. 


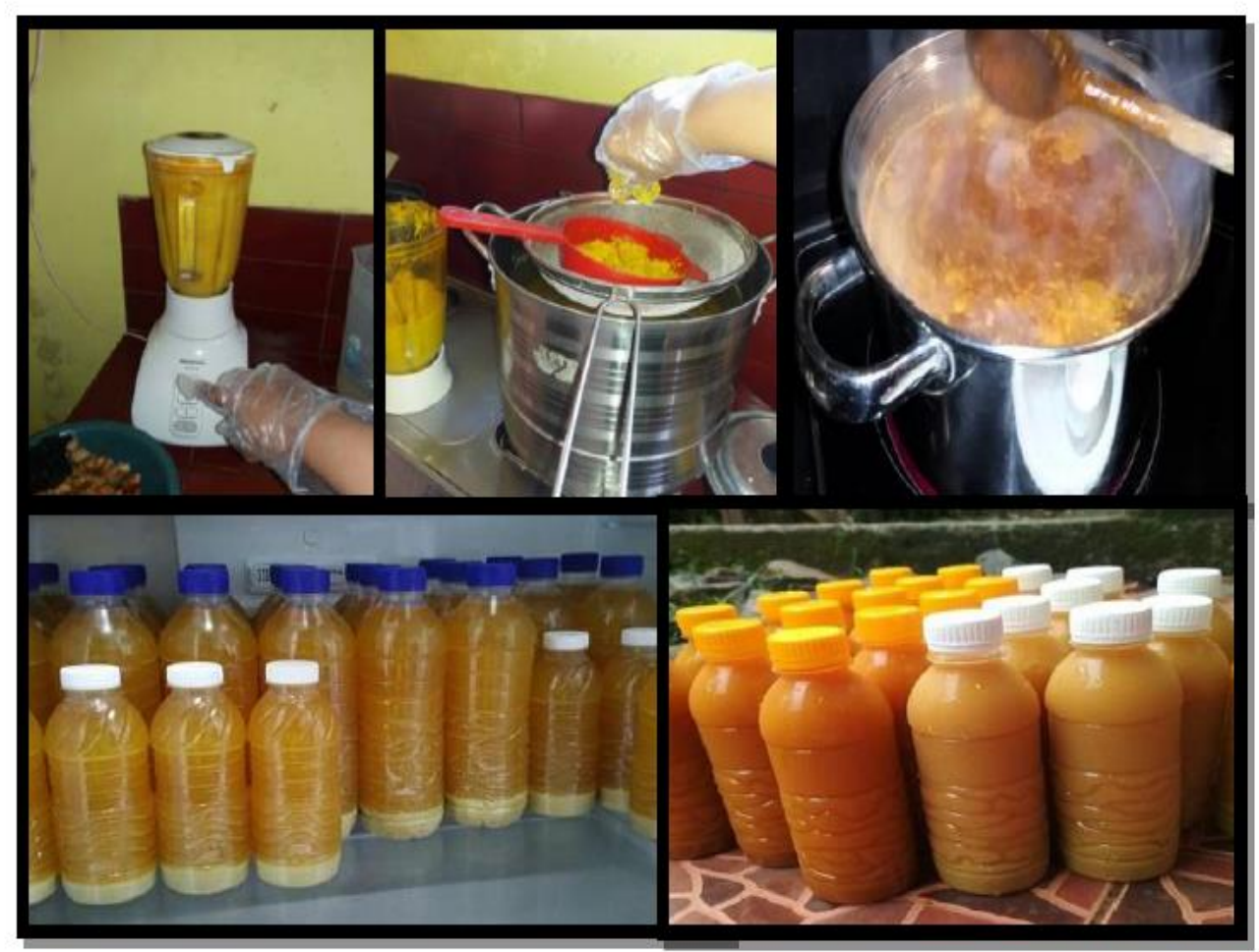

Gambar 1. Proses Pembuatan Jamu Tradisional sebelum Modifikasi Mesin

Proses perebusan yang dilakukan secara manual dengan menggunakan panci berukuran 10 liter dirasa kurang efektif. Perebusan manual ini membutuhkan waktu +3 jam dengan menggunakan kompor gas biasa. Tidak hanya itu saja, proses penyaringan yang dilakukan secara manual tentunya menyebabkan kurangnya kualitas dari produk jamu yang dihasilkan. Bahkan tidak jarang, karena lamanya produksi jamu ini menyebabkan jamu terkontaminasi dengan udara luar sehingga menimbulkan resiko tumbuhnya bakteri sehingga jamu tersebut tidak dapat bertahan lama. Jamu ini hanya dapat bertahan selama 4 hari saja pada suhu normal atau 6 hari apabila disimpan dalam lemari pendingin. Keadaan inilah yang menyebabkan mitra membatasi jumlah produk jamu. Padahal permintaan pasar akan jamu ini semakin hari semakin meningkat, terutama pada saat lebaran dan natal. Melihat hal tersebut, maka diperlukan suatu penyelesaian dalam meningkatkan kuantitas dan kualitas produk jamu milik mitra. Mengingat usaha jamu mitra ini merupakan usaha yang memiliki peluang bisnis besar di masyarakat. Dengan demikian tujuan dari pengabdian PKM (Program Kemitraan Masyarakat) ini, yaitu alih teknologi dalam memodifikasi mesin jamu guna meningkatkan kualitas dan kuantitas jamu yang diproduksi oleh mitra ini.

\section{Metode Pelaksanaan}

Metode yang ditawarkan dalam pelaksanaan Hibah Program Kemitraan Masyarakat (PKM) yaitu diskusi, pelatihan, pendampingan. Pelatihan ini membahas tentang pengoperasian dan perawatan mesin produksi jamu. Langkah - langkah solusi guna menyelesaikan permasalahan mitra adalah sebagai berikut:

\section{Diskusi dengan Mitra}

Dalam upaya menggali informasi tentang permasalahan yang dihadapi oleh mitra, maka perlu diadakannya diskusi untuk mengetahui kekuatan dan kelemahan mitra sehingga didapatkan solusi penyelesaian. Keterlibatan mahasiswa sangat diperlukan dalam diskusi ini agar dapat memperlancar jalannya diskusi. Untuk itu, dilibatkan 3 mahasiswa untuk membantu pelaksanaan diskusi dengan mitra. Keterlibatan mahasiswa ini dimaksudkan untuk menumbuhkan jiwa kewirausahaan dan untuk mengetahui alur produksi pembuatan jamu dari pembuatan sampai pemasaran sehingga dapat dijadikan referensi dalam mengembangkan usaha. Diskusi dengan mitra ini bertujuan untuk mencari penyelesaian 
dari permasalahan dan menggali potensi usaha mitra serta melihat peluang pasar. Sebagai contoh permasalahan yang dihadapi adalah ketersedian alat produksi sehingga menyebabkan produktifitas rendah, maka dilakukan diskusi guna meningkatkan produksi sehingga dapat memenuhi permintaan pasar. Keterlibatan mitra dalam kegiatan ini adalah menyediakan tempat dan fasilitas dalam pelaksanaan kegiatan. Partisipasi aktif mitra dalam memberikan informasi turut mendukung keberhasilan kegiatan ini.

\section{Pelatihan Pengoperasian Mesin Modifikasi Produksi dan Perawatan Mesin}

Pengabdi dibantu oleh ahli mesin untuk melatih mitra dalam mengoperasikan mesin produksi. Selain itu pada pelatihan juga diajarkan perawatan terhadap mesin produksi agar tetap bersih setelah dipakai dan mesinnya awet.

\section{Pendampingan}

Pendampingan usaha jamu tradisional ini dimulai dari: a) Penyediaan alat produksi berupa tangki air kapasitas 50 liter dan alat pemanas (kompor) 2 buah serta masing-masing tangki terhubung dengan pipa yang dipisahkan dengan stop kran. Jamu yang sudah dimasak dapat langsung dialirkan ke tangki penampung untuk pencampuran dengan bahan yang lain. Alat ini disertai penyaring. b) Pembuatan mesin penggiling kapasitas besar dengan bantuan ahli mesin.c) Pengoperasian dan perawatan mesin. dan d) Produksi jamu menggunakan mesin modifikasi. Diagram alur kegiatan PKM dapat dilihat pada Gambar 2.

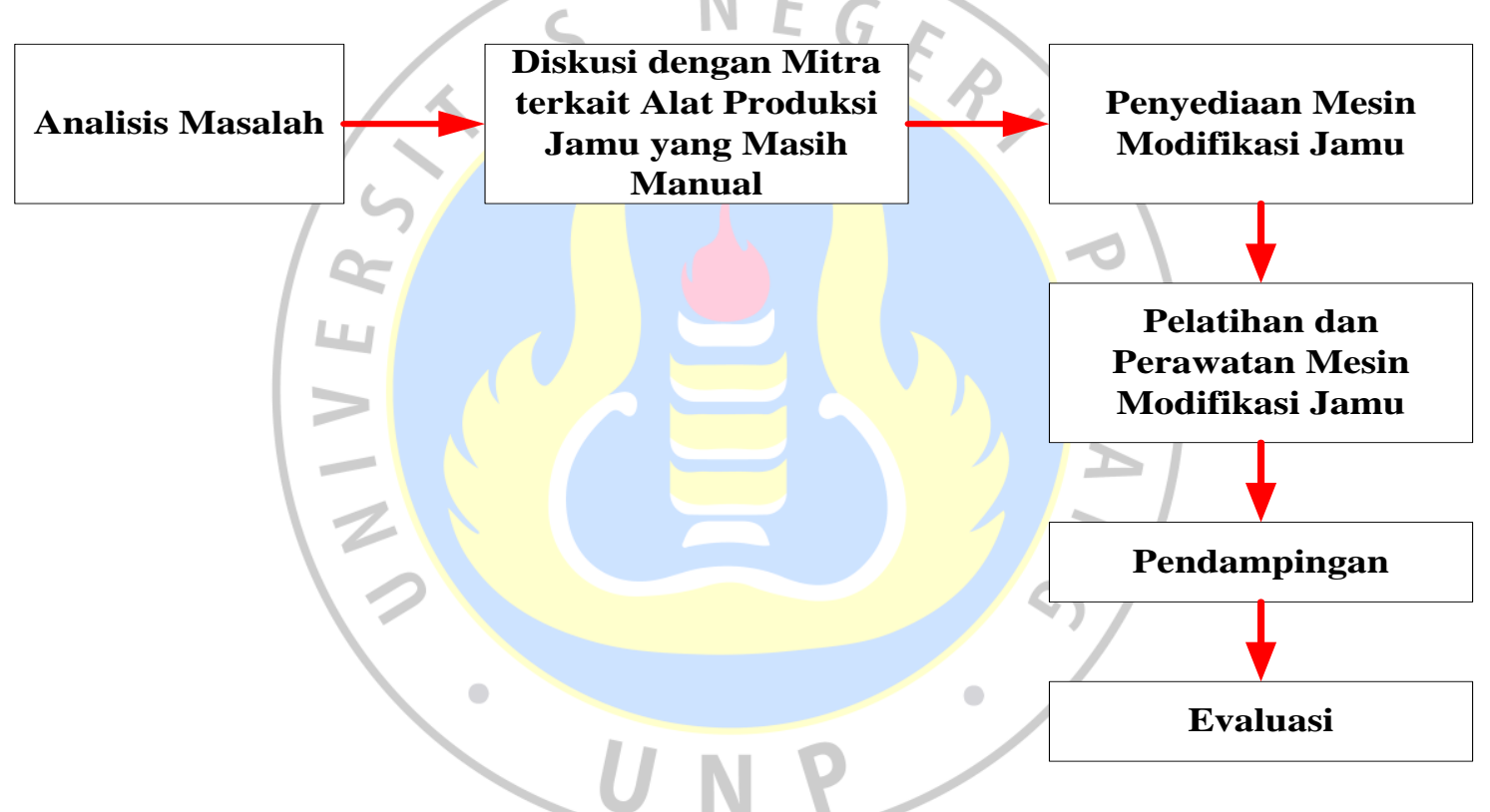

\section{Gambar 2. Diagram alur Kegiatan PKM}

\section{Hasil dan Pembahasan}

Pengabdi melakukan pengaturan jadwal pada saat kegiatan pengabdian. Hal ini dilakukan karena lokasi mitra yang merupakan daerah macet sehingga penjadwalan sangat penting dilakukan. Jadwal kegiatan pengabdian tidak dilakukan pada akhir pekan yaitu Sabtu dan Minggu. Pengabdi dan mitra berdiskusi guna menjadwalkan hari Senin sampai Kamis untuk menghindari kemacetan.

Tempat kegiatan pengabdian dilakukan di rumah mitra sebagai bentuk partisipasi aktif mitra pada kegiatan PKM ini. Ibu Erni selaku mitra menyediakan tempat ketika pengabdi melaksakan pelatihan pengoperasian mesin modifikasi jamu dan perawatan mesin modifikasi jamu. Kegiatan pelatihan diikuti oleh mitra dan pegawainya. Mesin modifikasi jamu dapat dilihat pada Gambar 3. 


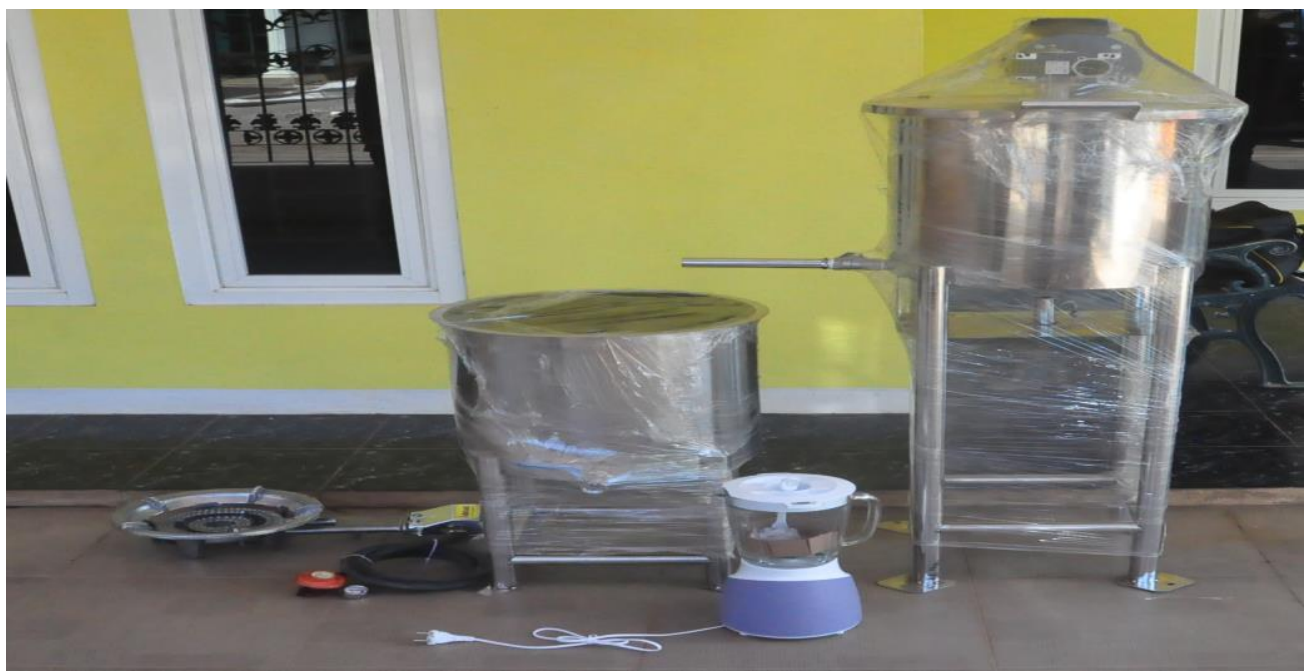

\section{Gambar 3. Mesin Modifikasi Jamu}

Selanjutnya kegiatan pelatihan pengoperasian mesin modifikasi jamu dan perawatan dibantu oleh ahli mesin. Hasil produksi jamu setelah penggunāan mesin modifikasi mengalami peningkatan yang cukup tajam. Berikut dipaparkan hasil 3 bulan sebelum penggunaan mesin modifikasi dan 2 bulan setelah penggunaan mesin modifikasi.

Tabel 1. Hasil Produk Jamu Sebelum dan Setelah Modifikasi Mesin

\begin{tabular}{ccccccc}
\hline & & \multicolumn{2}{c}{$\begin{array}{c}\text { Sebelum Penggunaan Mesin } \\
\text { Modifikasi Jamu/Bulan (Dus) }\end{array}$} & $\begin{array}{c}\text { Setelah Penggunaan } \\
\text { Mesin Modifikasi } \\
\text { Jamu/Bln (Dus) }\end{array}$ \\
\cline { 3 - 8 } & & $\mathbf{1}$ & $\mathbf{2}$ & $\mathbf{3}$ & $\mathbf{4}$ & $\mathbf{5}$ \\
\hline 1 & Sinom & 28 & 31 & 30 & 127 & 153 \\
\hline 2 & Kunci Sereh & 23 & 20 & 19 & 121 & 146 \\
\hline 3 & Kunyit Asam & 20 & 26 & 23 & 124 & 152 \\
\hline \multicolumn{2}{c}{ Total } & 71 & 77 & 72 & 372 & 451 \\
\hline
\end{tabular}

Selain itu pengabdi juga melakukan pendampingan pada saat kegiatan PKM ini. Pengabdi juga meminta evaluasi dari mitra terkait kegiatan pengabdian. Evaluasi dilakukan untuk mengetahui kelebihan dan kekurangan dari kegiatan pengabdian PKM. Kegiatan evaluasi pengabdian dapat dilihat pada Gambar 4.

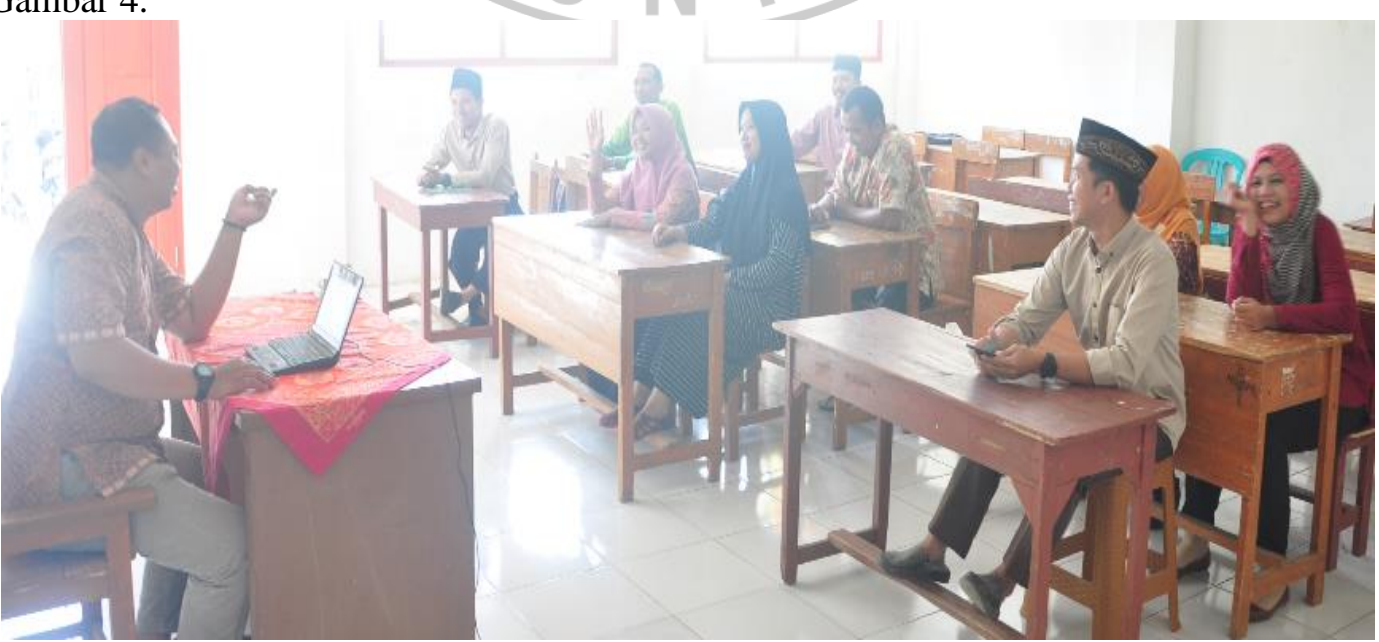

Gambar 4. Evaluasi Kegiatan Pengabdian 
Berdasarkan hasil pada paparan di atas maka penjadwalan pengabdian dilakukan dengan mempertimbangkan kemacetan sehingga tidak dilakukan pada akhir pekan. Selain itu penjadwalan juga dilakukan setelah berdiskusi dengan mitra karena agar antara pengabdi dan mitra dapat melakukan kegiatan secara lancar.

Mitra juga berperan aktif pada saat pengabdian dengan menyediakan tempat pengabdian. Tempat pengabdian digunakan untuk pelatihan, produksi dan pendampingan. Mitra sangat proaktif dengan kegiatan dengan selalu hadirnya mitra selama kegiatan pengabdian. Hal ini sejalan dengan pendapat yang mengatakan bahwa partisipasi aktif mitra sangat menentukan keberlanjutan dan keberhasilan program (Murniasih, 2018).

Hasil produksi jamu mengalami peningkatan yang cukup tajam setelah menggunakan mesin modifikasi. Berdasarkan paparan data pada hasil sebelum penggunaan mesin modifikasi jamu, maka rata-rata setiap bulan mitra hanya dapat memproduksi jamu sekitar 70 dus. Dialog antara mitra dan pengabdi menunjukkan permintaan pasar cukup banyak tetapi mitra tidak dapat memenuhi permintaan karena dalam satu bulan hanya bisa memproduksi sekitar 70 dus. Setelah penggunaan mesin modifikasi jamu maka pada bulan ke 4 mitra dapat memproduksi jamu sebanyak 5 kali lipat lebih dibandingkan produksi sebelum mesin modifikasi atau sekitar 372 dus. Selanjutnya pada bulan ke 5 permintaan pasar terus naik dan mitra masih bisa memenuhi permintaan pasar yang mengalami kenaikan hambir tujuh kali lipat atau sekitar 451 dus. Dari hasil yang dipaparkan dapat dilihat kenaikan produksi jamu setelah adanya mesin modifikasi. Hal ini sejalan dengan pendapat yang mengatakan modifikasi mesin dapat meningkatkan produksi (Ferdiani, 2018)

Hasil evaluasi dengan mitra menunjukkan bahwa mitra sangat senang dengan adanya kegiatan PKM ini karena setelah menggunakan alat modifikasi jamu hasil produksi jamu ibu Erni mengalami peningkatan yang tajam. Mitra juga menghendaki adanya tindak lanjut dari kegiatan pengabdian ini.

\section{Kesimpulan}

Penggunaan mesin modifikasi jamu ternyata dapat meningkatkan produksi jamu. Diharapkan setelah adanya mesin modifikasi jamu mitra dapat memasarkan produk secara luas dengan manajemen pemasaran yang lebih baik.

\section{Daftar Pustaka}

Ferdiani, R. D., Murniasih, T. R., Wilujeng, S., \& Suwanti, V. (2018). Penambahan Alat Produksi Guna Meningkatkan Produktivitas Pengrajin Keset. Jurnal Pengabdian dan Pemberdayaan Masyarakat, 2(1).

Mangan, Y. (2003). Cara Bijak Menaklukan Kanker. Jakarta: Agromedia Pustaka.

Mohammad, M.M. (2007). Mukzizat Kedokteran Nabi. Jakarta: Qultum Media.

Murniasih, T. R., \& Ferdiani, R. D. (2018). Pelatihan Smart Digram Venn Pada Materi Himpunan SMP. Aksiologiya : Jurnal Pengabdian kepada Masyarakat, 2(2), 125-130. 